\title{
First report of Enterobacter soli associated with gastro-hepato infection of farmed fish, Channa striata in Malaysia
}

\begin{abstract}
The freshwater snakehead fish Channa striata is extensively distributed across tropical Africa and Asia. This fish becomes an important commodity in the aquaculture business that has been industrialized very fast over the last ten years. However, diseases brought economic loss to the industry estimated to be in billions. Although wild Channa striata are known to be highly resistant to diseases, the case under captivity may be different. For instance, an occurrence of selective mortality was found in a farm of Channa striata in Selangor, Malaysia. The etiology of the infection was attributed to a bacterium that belong to Enterobacteriaceae family. This family is known to be widely distributed in nature and was previously found to be involved in mortality of different fish species. Accordingly, 16S rRNA gene sequencing was used to identify bacteria isolated from skin and liver of moribund fish; the present research confirmed that the causative disease agent had been Enterobacter soli. To our best knowledge, it is the first to report this bacterium species as a disease causative agent in fish. Furthermore, clinical and histopathological changes of healthy fish samples were followed up applying the Koch's procedure.
\end{abstract}

Keywords: Snakehead fish, Enterobacteriaceae, histopathological, 16S rRNA
Volume 10 Issue 2 - 2019

\author{
Ihlam Ibrahim Eid, Geok Yuan Annie Tan, \\ Subha Bhassu \\ Institute of Biological Sciences, Faculty of Science, University of \\ Malaya, Malaysia
}

\begin{abstract}
Correspondence: Subha Bhassu, Institute of Biological Sciences, Faculty of Science, University of Malaya 50603, Kuala Lumpur, Malaysia, Tel +60108907460, Fax +60379675908, Email subhabhassu@um.edu.my
\end{abstract}

Received: January 02, 2019 | Published: March 01, 2019

\section{Introduction}

The freshwater snakehead fish Channa striata ${ }^{1}$ is from the family of Channidae; it has a wide variety of habitats ranging from lakes, rivers, ponds, swamps, canals and rice fields. Geographically, their natural habitats extensively include south Asia, south China, Indochina, and Sunda Islands. ${ }^{1,2}$ In Malaysia, the fish is commonly known as Haruan. It is popularly eaten by local people to enhance wound healing. This could be attributed to the fact that its fresh fillet was reported to contain an appreciable amount of arachidonic acid which is a precursor of prostaglandins, ${ }^{3}$ that plays a role in blood clotting and tissue growth. ${ }^{4}$ Its fresh fillet also contains high glycine, ${ }^{3,5}$ an amino acid required for collagen formation in human skin.

Over the last ten years, the aquaculture business has grown very fast in the Asia-Pacific region. ${ }^{6}$ Notwithstanding, the fact that aquaculture is the fastest growing food-production industry in the world the sector is plagued by diseases. The annual economic loss to the aquaculture industry through diseases is estimated to be billions of US dollars worldwide. ${ }^{7}$ Major pathogens that affect the industry include bacteria, ${ }^{8,9}$ fungi, ${ }^{10}$ viruses ${ }^{11}$ and parasites. ${ }^{12}$

Several types of bacteria are opportunistic pathogens; thus, can lead to mortalities when fish is under severe condition of stress. ${ }^{11}$ Enterobacteriaceae is extensively spread in nature. It is found in soil, water, faeces of humans and animals, insects, plants, plant materials, and dairy products. ${ }^{13}$ It comprised $50 \%$ of the microbes recovered from both water and fish of earthen pond fertilized with animal faecal waste. ${ }^{14}$ Enterobacteriaceae species were found to be involved in the mortality of different fish species such as Pangasianodon hypophthalmu. ${ }^{15}$ Mugil cephalus ${ }^{16}$ and O. niloticus. ${ }^{17}$ In this preliminary report, bacteria from infected Channa striata, were isolated and characterized and identified using 16SrRNA gene sequence. Furthermore, clinical and histopathological examinations were carried out to investigate the signs of the disease.

\section{Materials and methods}

\section{Bacteria isolation}

The Occurrence of selective mortality of Channa striata was observed in a fish farm in Selangor area, Malaysia. About 50 samples of fish caught from ponds were transported alive in containers partly filled by the same water of the fishpond to the laboratory of genomic and evolutionary biology at the University of Malaya, and they were kept in precleaned and sterilized aquaria filled with dechlorinated tap water. A randomly chosen sample of five sluggish moribund fish showed lethargy, reduced feeding, skin white lesions was taken. Fish were rinsed with de-ionized water then slayed and dissected inside the BSC (Biosafety cabinet). A swab from liver and deeply infected areas of the skin (after removing the scales) were taken and inoculated onto Tryptic soy agar (TSA) with $1 \% \mathrm{Na} \mathrm{Cl}$ added and nutrient agar. Plates were incubated at $30^{\circ} \mathrm{C}$ for 24 hours. Colonies were then sub-cultured for pure culture isolation. Six isolates of bacteria were identified. However, only one of them gave typical symptoms of the disease observed in the fish farm which is used in the $\mathrm{LD}_{50}$ and pathogenicity of the disease. Clinical and histopathological changes of healthy and challenged fish samples were reported following the Koch's procedure to confirm the causative agent.

\section{Amplification of I 6S rRNA and sequencing}

Isolated bacteria were grown in nutrient broth with $1 \% \mathrm{Na} \mathrm{Cl}$ added. Inoculated overnight at $30^{\circ} \mathrm{C}$. DNA of the bacteria was extracted from the isolates describedvabove by a Qiagen kit following the manufacturer protocol. The $16 \mathrm{~S}$ rRNA gene was amplified by a 
forward primer (27F 5'AGAGTTTGATCCTGGCTCAG3') and a reverse primer (1492R 5'TACGGTTACCTTGTTACGACTT3'). Amplification was achieved in a thermal cycler (Eppendorf Master cycler gradient; Eppendorf, Hamburg, Germany), using the following programs: at $94^{\circ} \mathrm{C}$ for $5 \mathrm{~min}(1 \mathrm{cycle})$, at $94^{\circ} \mathrm{C}$ for 40 seconds $(35$ cycles), 40 seconds at $53^{\circ} \mathrm{C}, 40$ seconds at $72^{\circ} \mathrm{C}$ and a finally 1 cycle for 5 minutes at $72^{\circ} \mathrm{C}$. The products were checked by gel electrophoresis through 1\% agarose in the TBE (Tris-borate EDTA) buffer. Then Qiagen Gel purification kit (Germany) was used for purification of the product which was sequenced with an ABI PRISM 3730xl Genetic Analyzer of Applied Biosystems, USA with Big Dye ${ }^{\circledR}$ Terminator v3.1 Cycle Sequencing Kit. The amplified 16S rRNA gene sequences were blast analyzed.

\section{LD $_{50}$ experiment}

An amount of approximately $10 \mathrm{mg}$ ( 3 full loops) of the fresh pure culture of the bacteria mixed with $1 \mathrm{ml}$ PBS, then 10-fold dilutions were prepared by the serial dilution method. This dilution $(10 \mathrm{mg}$ in 1 $\mathrm{ml}$ ) was used as the base for the serial dilutions. Four serial dilutions with approximately $10^{7}, 10^{6}, 10^{5}$ and $10^{4} \mathrm{CFU} / \mathrm{ml}$ were consecutively prepared to be used for the $\left(\mathrm{LD}_{50}\right)$ experiment. From each of the above-mentioned dilutions, $0.2 \mathrm{ml}$ bacterial suspension was injected intramuscularly to each individual fish of the 4 groups $(n=10)$ which were previously stocked in separate tanks. Tricaine methanesulfonate (MS-222) at a concentration of $150 \mathrm{ppm}$ was used to anesthetize fish prior to injection. Each group was kept in a separate aquarium labeled properly to recognize the dose. The experimentally infected fish were observed up to 15 days. The mortality record of the $\mathrm{LD}_{50}$ value was worked out. The number of colonies in the plate that killed half of the population $\left(\mathrm{LD}_{50}\right)$ was 32 colonies. The amount of bacteria suspension used was $200 \mu \mathrm{l}$ so the calculation of CFU for $\mathrm{LD}_{50}$ as follows:

$\mathrm{CFU} / \mathrm{ml}=$ (no. of colonies $\mathrm{x}$ dilution factor $) /$ volume of culture plate

$$
=32 \times 1000000 / 0.2 \mathrm{ml}=16 \times 10^{7} \mathrm{cfu} / \mathrm{ml}
$$

This study precisely presented the official ethical review board
(UM ICUCA) for approval [Ethic No. ISB/13/03/2015/IE (R)].

\section{Pathogenicity experiment}

The intramuscular injection technique, a method applied by several investigators ${ }^{18-20}$ was used to detect both the effectiveness of the method in initiating the disease and the pathogenicity of the bacteria. One $\mathrm{ml}$ of sterile and disposable insulin needles was used for intramuscular injection. A total of 30 fish was injected with 0.2 $\mathrm{ml}$ of $\mathrm{LD}_{50}\left(16 \times 10^{7} \mathrm{CFU} / \mathrm{fish}\right)$ bacterial dosage below the fore part of the dorsal fin. Disinfection by cotton containing $70 \%$ alcohol was used before injection. Another group of fish $(n=10)$ was injected by the same dose of the PBS as a control. The fore part of the dorsal fin was selected for injection because it contains the deep muscle. These two groups of experimented fish were realized in separated aquaria, and they were noticed up to 15 days of the experimental length for any changes in the clinical appearances, and they have been recorded appropriately.

Every morning about $70 \%$ of the water is changed and the fish is provided with pellet feed. The clinical signs observed were lethargy, loss of appetite, lesion of the skin and mortality. Liver and muscle samples were taken from moribund fish and kept in 10\% phosphatebuffered formalin solution for histopathological examination.

\section{Results}

\section{Molecular identification using I6S rRNA sequence}

The identification of Enterobacter soli bacterium is based on the sequence of $16 \mathrm{~S}$ rRNA gene (1160bp). The sequence was identified using Ez Taxon database. ${ }^{21}$ Then characterized and matched for its similarities towards other relative strains. Identification search of nucleotide sequences through the Ez Taxon server showed that Enterobacter soli strain LF7a had the highest (99.31\%) similarity with the bacterium isolated in this study from the fish. Whereas the Enterobacter asburiae strain JCM 6051 and Enterobacter cloacae strain LMG 2683 was $98.36 \& 98.18 \%$ respectively (Table $1 \&$ Figure 1).

Table I Identification similarity of isolated bacteria Enterobacter soli with other species from Ez Taxon based on I6S rRNA gene sequencing

\begin{tabular}{lllll}
\hline Species strain & Strain & $\begin{array}{l}\text { Ez Taxon } \\
\text { accession no. }\end{array}$ & Similarity\% & Completeness (\%) \\
\hline Enterobacter soli & LF7a & CP003026 & 99.31 & 100 \\
Enterobacter asburiae & JCM 605I & AB004744 & 98.36 & 97.26 \\
Enterobacter cloacae & LMG 2683 & Z96079 & 98.18 & 100 \\
Enterobacter cloacae subsp. cloacae & ATCC I3047 & CP001918 & 98.1 & 100 \\
Enterobacter aerogenes & KCTC 2190 & CP002824 & 98.01 & 100 \\
Enterobacter ludwigi & EN-II9 & JTLO0I00000I & 97.93 & 100 \\
Enterobacter kobei & CIP I05566 & AJ50830I & 97.84 & 99.32 \\
Enterobacter cancerogenus & LMG 2693 & Z96078 & 97.83 & 100 \\
Enterobacter hormaechei & ATCC 49I62 & AFHR0I000079 & 97.41 & 100 \\
Enterobacter mori & LMG 25706 & GL890774 & 97.23 & 100 \\
Enterobacter xiangfangensis & I0-I7 & HF679035 & 97.22 & 97.61 \\
Enterobacter siamensis & C236I & HQ8888848 & 96.02 & 97.74
\end{tabular}




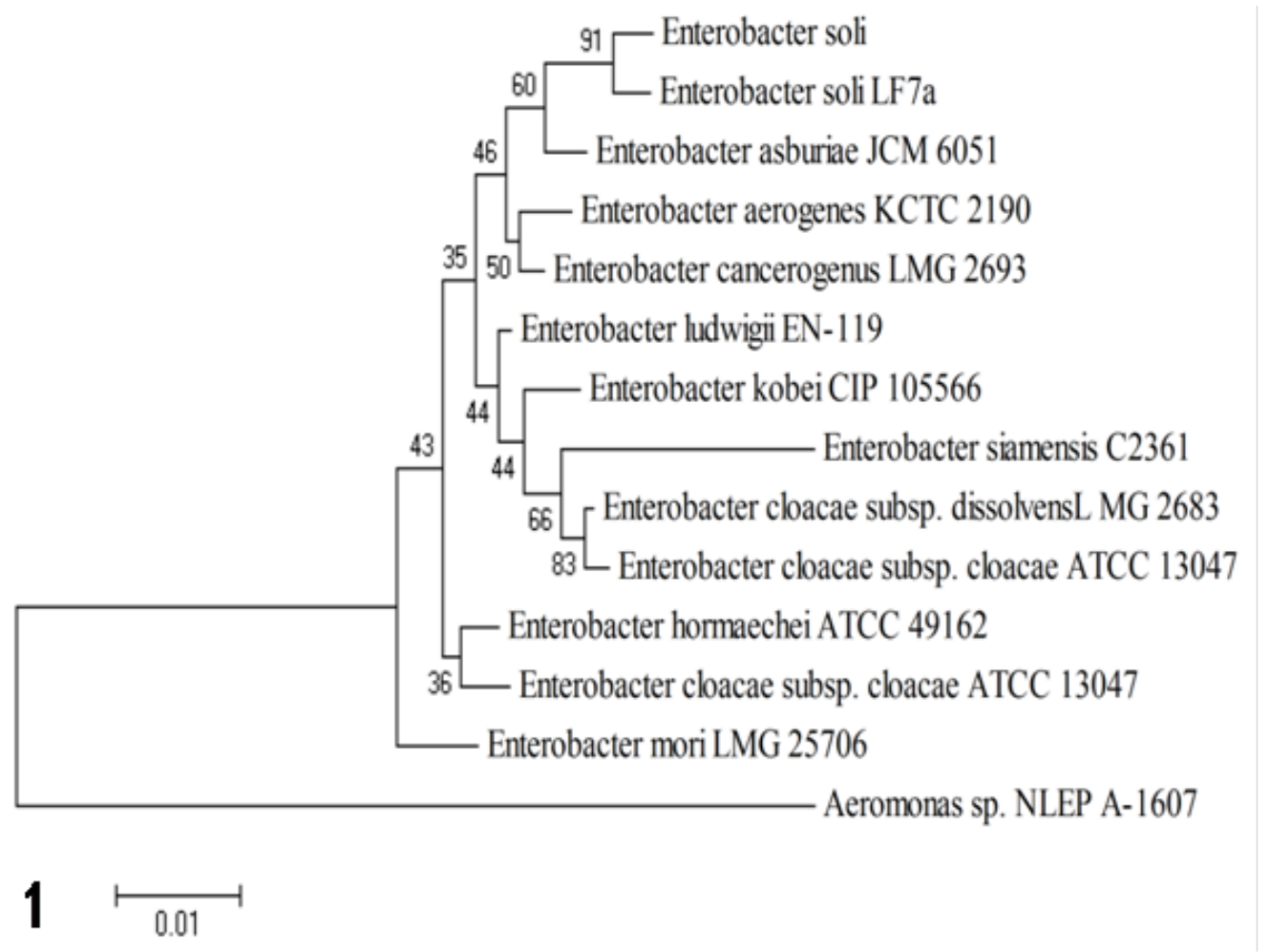

Figure I Phylogenetic tree deduced from the I6S rRNA gene sequences of the isolated bacterium with other Enterobacter spp. reconstructed by the neighbour-joining method. The numbers shown at the branches denote the bootstrap majority consensus values of I000 replicates.

\section{Experimental infection of fish}

\section{Clinical signs}

No any clinical signs of the disease or abnormal behaviour were observed within the control group of fish (PBS-injected) throughout the experiment period. Signs were observed in fishes injected with Enterobacter soli. Three days after the injection, the main clinical signs observed in fish injected with the bacteria included scale loss and white skin lesions (Figure 2). Seven days' post-injection, skin lesions further developed into ulcerations. On the $10^{\text {th }}$ day of post injection fish behaviors of the swimming were also affected, as most fish were practiced swimming with a tethering movement, with unnatural backward and forward activity. On the $14^{\text {th }}$ day of the post injection Moribund fish showed weakness with loss of appetite, and remained at the surface of the tank water before dying.

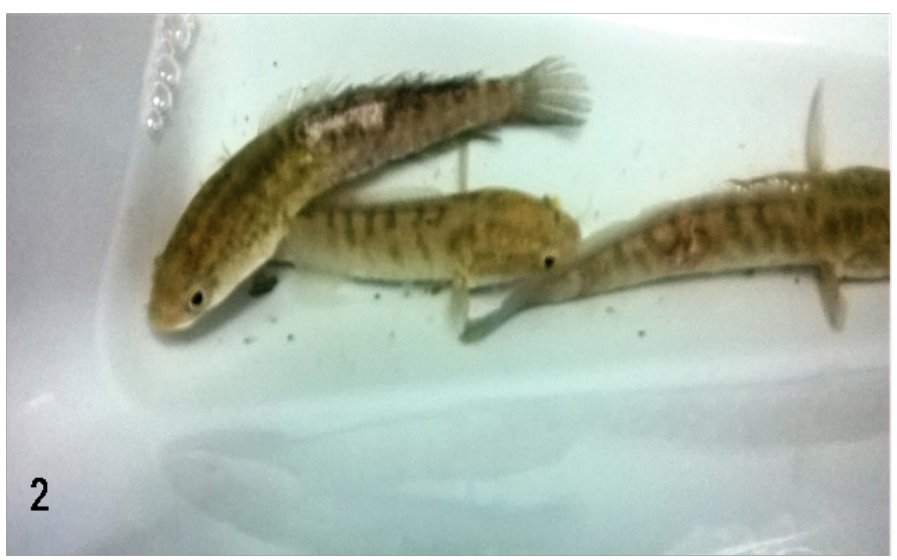

Figure 2 Clinical signs of the infected Channa striata with isolated Enterobacter soli. Photo was taken 3 days post infection while the fish was alive inside the water.

\section{Histopathological changes}

On histopathological examination of the liver of the injected fish, blood congestion in the blood vessel was observed in addition to hemorrhage and necrosis (Figure 3 ) beside rupture of central vein lining (Figure 4). The liver also showed dilation and congestion of central vein (Figure 5) (Figure 6). The pathological findings in the muscle of challenged fish included degeneration in muscle bundles and aggregations of inflammatory cells among them.

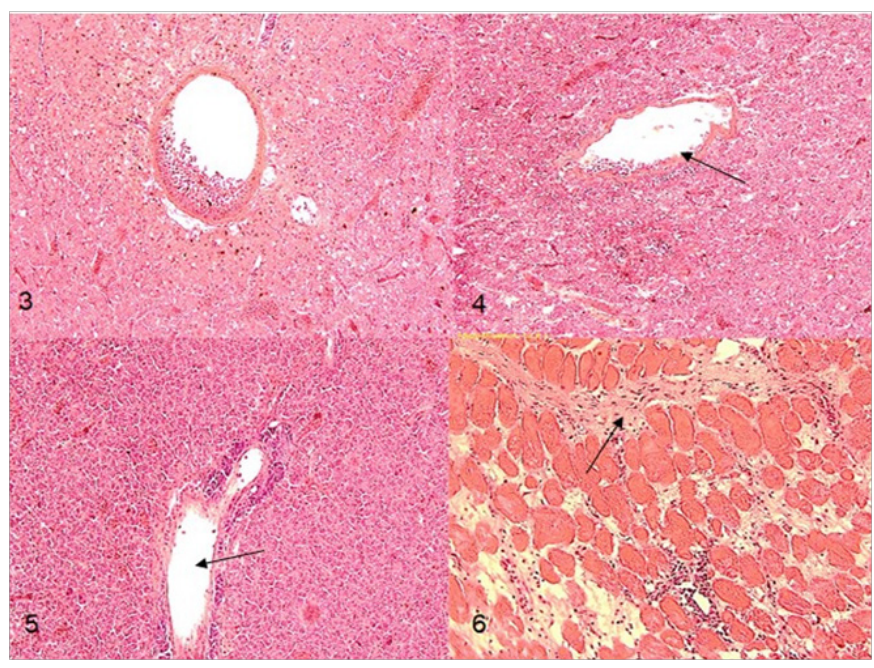

Figure 3-6 Channa striata liver infected with Enterobacter soli bacteria.

(Figure 3 Early inflammatory cells infiltration in blood vessels, haemorrhage and necrotic area. Figure 4 rupture of central vein lining (arrow) with haemorrhage and blood congestion. Figure 5 Marked dilation (arrow) and congestion of central vein. Figure 6 Channa striata muscle with acute inflammation and neutrophilic infiltrate (arrow) had led to necrosis and loss of muscle fibre structure. (H\&E staining)). 


\section{Discussion}

Currently, the bacterial family Enterobacteriaceae has 53 genera and over 170 named species ${ }^{10}$ indicating its importance. Hitherto a small number of these species, if any, were isolated from warmblooded vertebrates. ${ }^{22}$ Its main genera are Escherichia, Proteus, Klebsiella, Citrobacter and Enterobacter. ${ }^{23}$ The aim of the present study is to investigate the causative agents elaborated in observed selective mortalities of the Channa striata fish in aquaculture premises in Malaysia. Results revealed that Enterobacter soli, first isolated from soil by Manter et al., ${ }^{24}$ was the causative agent for these mortalities. As $C$. striata fish are found in freshwater bodies such as rivers and ponds, contamination by bacteria through run-off water to these water bodies, which is the ultimate source of water for tropical rivers, could not be excluded. Recently, 37 Enterobacteriaceae strains were isolated from 40 Oreochromis niloticus fish samples. ${ }^{17}$ However, as a disease-causing agent Enterobacter Cloacae had earlier been found to have possible involvement with fish infection. ${ }^{16}$ Thus, the current study is the first to report Enterobacter soli as a disease causative agent in fish.

In this study, the main clinical signs in experimentally diseased fish were skin ulcer, dullness, appetite loss and abnormal swimming behavior which may be pretty similar to those noted by Hassan et al. Histology is the study of tissues, including their role in the body, their anatomy, their interaction with body systems and the ways they are affected by the disease. In this study, we observed hepatic lesions including blood congestion that may be due to increased blood influx to the liver. This finding is in line with ${ }^{25}$ in Orechromis niloticu. ${ }^{26}$ and in channel catfish infected with Edwardsiella tarda. Sinusoids and small blood vessels congestion were observed that makes blood movement from the hepatic portal vein and hepatic artery into the central vein quite hard. These difficulties in blood flow cause dilation of sinusoids that may reach the extent of rupture of blood vessels; similar findings were also observed by Ikpesupp and Ezemonye. ${ }^{27}$ Other histological alterations observed microscopically in the liver of challenged fish were cellular degeneration and necrosis which were also observed by Alaa; ${ }^{28}$ Hassan et al. ${ }^{17}$ who elucidated that Inflammatory and necrotic changes in rainbow trout fry and cyprinids indicate typical acute bacterial septicaemia caused by Citrobacter freundii. A notable gathering of inflammatory cells infiltration next to some blood vessels could be attributed to the presence of necrotic cells that act as irritant substances that bring these inflammatory cells. This is fairly consistent with Mekkawy. ${ }^{25}$ In general, the accumulation of these cells is an actual response of body tissue facing injury or bacterial infection. ${ }^{29}$

Histological changes in the muscle include inflammatory cells infiltration due to the bacterial infection. Therefore, this result is in line with the findings of El-Banhawy ${ }^{29}$ who studied the pollution of Solea vulgaris and Tilapia zillii fish from a lake that receives large amounts of contaminated drainage water. ${ }^{30-32}$

\section{Conclusion}

In this study, we isolated Enterobacter soli from diseased fishy, and indicated that it is the causative agent of the selective mortality observed in the Channa striata. Furthermore, clinical and histopathological changes of healthy fish samples and challenged fish were reported following the Koch's procedure to confirm the causative agent. The current study is the first to report Enterobacter soli strain as a disease causative agent in fish.

\section{Acknowledgements}

We would like to express thank to the University of Malaya for grant FL0102012F given by the Centre for Research in Biotechnology for Agriculture (CEBAR) to fund this work, as well as the GRA internship awarded to Ms. Ihlam Ibrahim Eid.

\section{Conflicts of interest}

Author declares no conflicts of interest.

\section{References}

1. Hossain MK, Latifa GA, Rahman MM. Observations on induced breeding of snakehead murrel, Channa striatus (Bloch, 1793). Int $J$ Sustain Crop Prod. 2008;3(5):65-68.

2. Song LM, Munian K, Abd Rashid Z, et al. Characterisation of Asian snakehead murrel Channa striata (Channidae) in Malaysia: an insight into molecular data and morphological approach. The Scientific World Journal. 2013:917506.

3. Mat Jais AM, Matori MF, Kittakoop P, et al. Fatty acid composition in mucus and roe of Haruan, Channa striatus, for wound healing. Gen Pharmacol. 1998:30(4):561-563.

4. Bowman WC, Rand MJ. Textbook of Pharmacology. $2^{\text {nd }}$ edn. Blackwell Scientific Publications. London. 1980.

5. Zakaria ZA, Mat Jais AM, Goh YM, et al. Amino acid and fatty acid composition of an aqueous extract of Channa striatus (Haruan) that exhibits antinociceptive activity. Clin Exp Pharmacol Physiol. 2007;34(3):198-204.

6. Caipang CMA, Lucanas JB, Lay-Yag CM. Updates on the vaccination against bacterial diseases in tilapia, Oreochromis spp. and Asian seabass, Lates calcarifer. AACL Bioflux. 2014;7(3):184-193.

7. Pridgeon JW, Klesius PH. Major bacterial diseases in aquaculture and their vaccine development. Animal Science Reviews. 2013;141.

8. Frans I, Michiels CW, Bossier P, et al. Vibrio anguillarum as a fish pathogen: virulence factors, diagnosis and prevention. J Fish Dis. 2011;34(9):643-634

9. Wang W. Bacterial diseases of crabs: a review. J Invertebr Pathol. 2011;106(1):18-26.

10. Public Health England. Identification of Enterobacteriaceae. UK Standards for Microbiology Investigations. 2015;16(4).

11. Vega-Heredia S, Mendoza-Cano F, Sanchez-Paz A. The infectious hypodermal and haematopoietic necrosis virus: a brief review of what we do and do not know. Transbound Emerg Dis. 2012;59(2):95-105.

12. Brooker AJ, Shinn AP, Bron JE. A review of the biology of the parasitic copepod Lernaeocera branchialis (L.,1767) (Copepoda: Pennellidae). Adv Parasitol. 2007;65:297-341.

13. Neto RJ, Yano T, Beriam LOS, et al. Comparative RFLP- ITS Analysis between Enterobacter cloacae strains isolated from plants and clinical origin. Arq Inst Biol. 2003:70367-372.

14. Ogbondeminu FS, Okaeme AN. Comparative analysis of bacterial flora associated with water and fish in manured pond. Biosci Res Comm. 1989;1:103-108

15. Kumar KKP, Prasad RP, Raman S, et al. Association of Enterobacter cloacae in the mortality of Pangasianodon hypophthalmus (Sauvage, 1878) reared in culture pond in Bhimavaram, Andhra Pradesh, India. Indian J Fish. 2013;60(3):147-149.

16. Sekar TV, Santiago TC, Vijayan KK, et al. Involvement of Enterobacter cloacae in the mortality of the fish, Mugil cephalus. Lett Appl Microbiol. 2008;46(6):667-672. 
17. Hassan AHM, Noor-E1Deen AE, Galal HM, et al. Further Characterization of Enterobacteriaceae isolated from cultured freshwater fish in Kafr E Shiek Governorate: Clinical, biochemical and histopathological study with emphasis on treatment trials. Global Veterinaria. 2012;9(5):617629.

18. Sarkar MJA, Rashid MM. Pathogenicity of the bacterial isolate Aeromonas hydrophila to catfishes, carps and perch. Journal of the Bangladesh Agricultural University. 2012;10(1):157-161.

19. Hossain MF, Rahman MM, Sayed MA. Experimental infection of indigenous climbing perch Anabas testudineus with Aeromonas hydrophila bacteria. Progressive Agriculture. 2013;22(1-2):105-114.

20. Neely MN, Pfeifer JD, Caparon M. Streptococcus-zebrafish model of bacterial pathogenesis. Infect Immun. 2002;70(7):3904-3914.

21. Kim OS, Cho YJ, Lee K, et al. Introducing Ez Taxon: a prokaryotic $16 \mathrm{~S}$ rRNA Gene sequence database with phylotypes that represent uncultured species. Int J Syst Evol Microbiol. 2012;62(Pt 3):716-721.

22. Gordon David M, Frances Fitz Gibbon. The distribution of enteric bacteria from Australian mammals: host and geographical effects. Microbiology. 1999;145(10):2663-2671.

23. Cabral JP. Water microbiology. Bacterial pathogens and water. Int $J$ Environ Res Public Health. 2010;7(10):3657-3703.

24. Manter DK, Hunter WJ, Vivanco JM. Enterobacter soli sp. nov.: a lignindegrading $\gamma$-proteobacteria isolated from soil. Current microbiology. 2011;62(3):1044-1049.

25. Mekkawy IAA, Mahmoud UM, Wassif ET, et al. Protective roles of tomato paste and vitamin $\mathrm{E}$ on cadmium-induced histological and histochemical changes of a liver of Oreochromis niloticus (Linnaeus, 1758). Journal of Fisheries and Aquatic Science. 2012;7(4):240.
26. Darwish A, Plumb JA, Newton JC. Histopathology and pathogenesis of experimental infection with Edwardsiella tarda in channel catfish. Journal of Aquatic Animal Health. 2000;12(4):255-266.

27. Ikpesupp TO, Ezemonye LIN. Bioaccumulation and Histopathological Alterations in Liver Caused by Endosulfan Toxicity in Oreochromis niloticus. International journal of Advanced Biological and Biomedical Research. 2014;2(8):2395-2404.

28. Alaa GM. Biomarkers in Nile tilapia Oreochromis niloticus (Linnaeus, $1758)$ to assess the impacts of river Nile pollution: bioaccumulation, biochemical and tissues biomarkers. Journal of Environmental Protection. 2012;3:966-977.

29. El-Banhawy EI. Histopathological studies on the effect of the anticoagulant rodenticide" Brodifacoum" on the liver of the rat. $J$ Egypt Ger Soc Zool. 1993;12:185-227.

30. Mohamed FA. Histopathological studies on Tilapia zillii and Solea vulgaris from Lake Qarun, Egypt. World Journal of Fish and Marine Sciences. 2009;1(1):29-39.

31. Ramaiah N. A review on fungal diseases of algae, marine fishes, shrimps and corals. Indian Journal of Marine Sciences. 2006;35:380-387.

32. Sousa JAD, Silva-Souza ÂT. Bacterial community associated with fish and water from Congonhas River, Sertaneja, Paraná, Brazil. Brazilian archives of Biology and Technology. 2001;44(4):373-381. 